\title{
RÉBAY MAGDOLNA
}

\section{A pozsonyi evangélikus gimnázium a dualizmus korában különös tekintettel az arisztokrata tanulókra*}

\section{Pozsony város és középiskolái}

A régi koronázási székhely, az országgyúlés egykori színhelye a dualizmus korában is jelentôs település maradt. Pozsony 1900-ban az ország ötödik legnépesebb városa volt. Ekkor 61537 polgári és 4330 katonai, azaz összesen 65867 lakosa volt. A lakosság száma a dualizmus korában elsődlegesen a betelepülésnek köszönhetően gyarapodott. Mobilitási célponttá a határhoz közeli fekvése, kulturális jelentôsége, a gazdasági, kereskedelmi és közlekedési életben betöltött funkciói miatt vált. ${ }^{1}$ Növekedési üteme azonban elmaradt Magyarország más városaiétól, ezért - Szarka szavaival - inkább nevezhető „stagnáló történeti város”-nak, mint „dinamikusan fejlödo” regionális alközpont”-nak. ${ }^{2}$ Pozsony etnikai határvonalak metszéspontjában feküdt, ami multikulturális településsé tette. A lakosság többsége német volt, de jelentős volt a magyarok és a szlovákok aránya is. A magyarok számaránya a dualizmus utolsó harmadában folyamatosan növekedett (lásd 1. táblázat). 1910-re nagyjából ugyanannyian lettek, mint a németek. ${ }^{3}$

A magyarosodás folyamatára így emlékezett vissza a tanulmányait a városban folytató műkritikus, irodalomtörténész Schöpflin Aladár: „... [A] 80-as évekeben indult nagy lendületnek az asszimiláció. $M a$ is fülemben van egy fiatal lány szava, aki a Mihály utcában 4 ezt mondta mamájának: Aber, Mama, sprechen wir ungarisch, es ist doch eleganter." 5 Egyre többen beszéltek tehát magyarul, 1890-ben a város lakosságának már az $51,2 \%-a .^{6}$

A lakosság felekezeti szempontból is igen heterogén volt. 1900-ban többsége (71\%) a katolikus egyház tagjának vallotta magát. A második legjelentősebb vallásfelekezet az evangélikus volt (14\%), a harmadik a zsidó (12\%). Igen kicsiny volt a református $(2 \%)$ és a görögkeleti egyház $(1 \%)$.

\footnotetext{
* A kutatás az MTA Bolyai János Kutatási Ösztöndijának köszönhetően valósult meg.

1 SZARKa 2005, 401-403., VutKOvich 1904. http://mek.oszk.hu/09500/09536/html/0017/7.html; Pozsony. http://mek.oszk.hu/00000/00060/html/084/pc008400.html\#7.

2 SZARKA 2005, 403.

3 Uo. 401-405.

${ }^{4}$ Az Óvárosban található, a város egyik legrégibb utcája.

${ }^{5}$ Idézi FUKÁRI 2003, 10.

${ }^{6}$ Magyar Statisztikai Évkönyv XIX., 1912, 22.
} 
1. táblázat. Pozsony lakosságának etnikai megoszlása (\%)

\begin{tabular}{|c|c|c|c|c|}
\hline & $\mathbf{1 8 8 0}$ & $\mathbf{1 8 9 0}$ & $\mathbf{1 9 0 0}$ & $\mathbf{1 9 1 0}$ \\
\hline Német & $63,4 \%$ & $59,9 \%$ & $50,4 \%$ & $41,9 \%$ \\
\hline Magyar & $15,1 \%$ & $19,9 \%$ & $30,5 \%$ & $40,5 \%$ \\
\hline Szlovák & $15,2 \%$ & $16,6 \%$ & $16,3 \%$ & $14,9 \%$ \\
\hline Cseh & n.a. & $1,3 \%$ & $1,6 \%$ & $1,2 \%$ \\
\hline Egyéb & $6,3 \%$ & $2,3 \%$ & $1,2 \%$ & $1,5 \%$ \\
\hline
\end{tabular}

Forrás: Kepecs szerk. 1996, 241.; Szarka 2005, 405.

Pozsony iskolaváros is volt, ahol a nagyobb felekezeteknek saját intézményeik voltak. Az evangélikus egyház elég erős volt ahhoz, hogy kiterjedt iskolarendszert múködtessen az alapfoktól a felsőfokig. Három népiskolát tartott fenn, abból kettőt a Belvárosban. Saját főgimnáziuma és teológiai akadémiája volt. Az árvák nevelésérôl pedig külön intézetekben gondoskodott. ${ }^{7}$

1. kép. A pozsonyi királyi katolikus főgimnázium új épülete

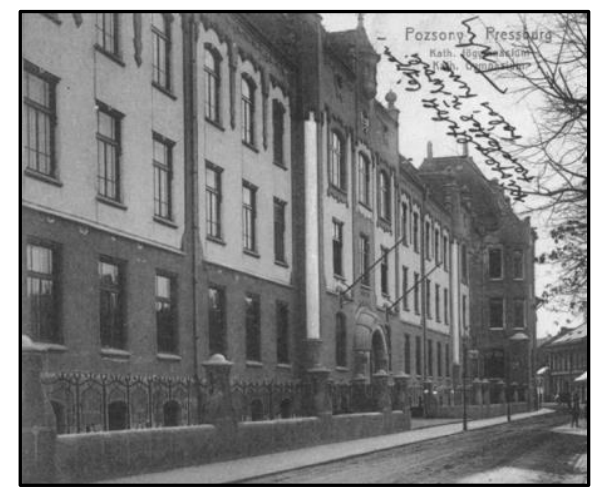

Forrás: Szecessziós Müvészeti Magazin.

http://www.szecessziosmagazin.com/imagemagazin3/miklos/pozsonyigimnazium.jpg

A dualizmus korában három fiú-középiskola és egy leány-középiskola múködött a városban. A királyi katolikus főgimnáziumot jezsuita gimnáziumként még Pázmány Péter alapította 1626-ban. A jezsuiták 1773-ig vezették az iskolát. Ezt követôen az állam múködtette, majd a bencés rend vezetése alá került (1812-1850). Az

\footnotetext{
7 VuTKOVICH 1904. http://mek.oszk.hu/09500/09536/html/0017/7.html.
} 
Entwurfot (1849) követően a régi-új tulajdonos, az állam nyolcosztályossá fejlesztette. Azon iskolák közé tartozott, amelyekben először lehetett az országban érettségi vizsgát tenni (1851). (A helyi evangélikus líceum tanulói is részt vettek ezen a megmérettetésen.) A tanítás nyelve német volt, míg az 1861. évi helytartótanácsi döntés alapján kétnyelvűvé nem vált. 1868-tól magyarul folyt az oktatás, de az 1880as évek elejéig a németet segédnyelvként használták. Az iskola tanulóinak száma növekedett: 1880/81-ben 410, 1900/01-ben 526, 1910/11-ben pedig 569 rendes tanuló iratkozott be. ${ }^{8}$ A régi iskolaépület ezért szűknek bizonyult. Így Lechner Ödön tervei alapján új, a modern kor követelményeinek megfeleló épületet emeltek, amelyet 1908-ban adtak át (lásd 1. kép). ${ }^{9}$

Az evangélikus főgimnáziumot a XVII. század elején alapították, történetével a következő fejezetben fogunk foglalkozni. ${ }^{10} \mathrm{~A}$ városi fớreáliskola (lásd 2. kép) a XIX. században keletkezett. 1850-ben hozták létre, ez volt az ország első ilyen típusú intézménye. Tanítási nyelve 1868-ban lett a magyar, addig a német volt. Falai közt az első érettségi vizsgát 1876/77-ben tartották. 1886-ban fenntartását átvette az állam. 1895-ben elkészült az új, korábbinál nagyobb létszámot befogadó otthona. Ez az iskola kevésbé volt népes, mint a királyi katolikus főgimnázium, de voltak évek, amikor több tanulója volt, mint az evangélikus fógimnáziumnak. Az 1880/81-es tanévre 303, az 1900/01-esre viszont 520 tanuló iratkozott be. 1910/11-ben 441 diák választotta az iskolát. ${ }^{11}$

2. kép. A pozsonyi állami főreáliskola épülete

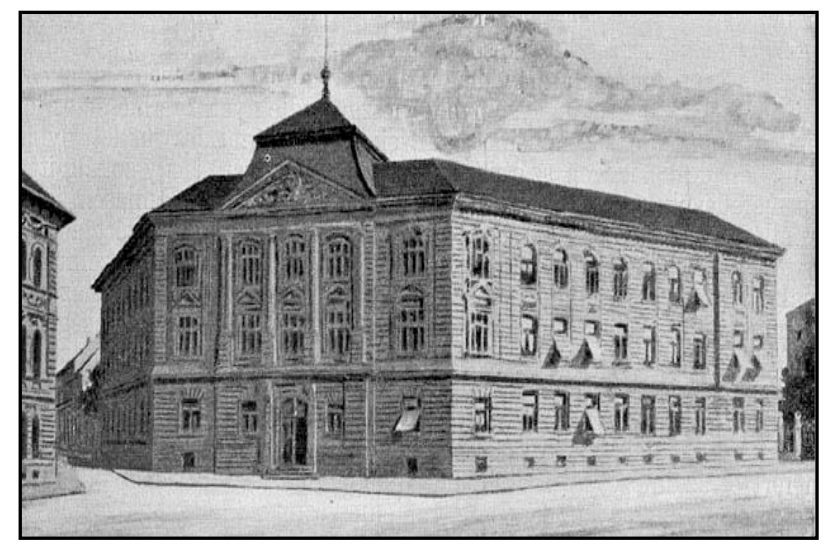

Forrás: Plachy - Pirchala 1904, bttp:/ / mek.oszk.hu/09500/09536/ btml/0017/19.btml

\footnotetext{
${ }^{8} \mathrm{Az}$ iskolának az arisztokraták nevelésében-oktatásában betöltött szerepével külön tanulmány keretében foglalkoztunk (lásd RéBAY 2015).

${ }^{9}$ MészÁros 1988, 241.

10 Uo. 241.

11 Uo. 242.; Plachy, Pirchala 1904. http://mek.oszk.hu/09500/09536/html/0017/19.html.
} 
A lányok közül középiskolai tanulmányok céljából 1895 után mind többen iratkoztak be az előbb említett intézményekbe. Az állami felsőbb leányiskolát ezért 1916/17-től felmenő rendszerben leánygimnáziummá alakították át. ${ }^{12}$

\section{A pozsonyi evangélikus gimnázium}

\section{Az iskola története}

Pozsonyban az egyházközség megalakulása után hamarosan Sturm rendszerét követő iskolát alapított, mely elemi, gimnáziumi, valamint filozófiai és teológiai képzést egyaránt nyújtott. Az intézmény 1607-ben kezdte működését. A kezdő diákokkal, míg a latin nyelvet el nem sajátították, németül - s egy ideig magyarul foglalkoztak. Politikai okokból még a XVII. században rövid ideig (1672-től) szünetelt az intézmény múködése. 1682-ben kezdték meg újjászervezését. Különösen sokat köszönhetett Bél Mátyásnak, aki 1714 és 1721 között a rektora volt. Az intézményt a magyarországi evangélikus tanintézetek anyaiskolájának tekintették. Fenntartója ugyan a pozsonyi egyházközség volt, ám tanügyi tekintetben sokáig az egyetemes gyűlés fennhatósága alá tartozott (s nem a dunáninneni egyházkerülethez).13

Az intézmény a XIX. században is három tagozatból állt, hivatalosan annak közepétől hívták líceumnak. Az akadémiai szint 1815-ben jogi képzéssel egészült ki. 1847-ben az elemi iskolai tagozat önállósult. Mivel a gimnázium nem felelt meg az Entwurf előírásainak, 1851-ben elvesztette nyilvánossági jogát. A fenntartó egyházközség ezt követően mindent megtett fejlesztése érdekében, s a gimnáziumot nyolc osztályossá bővítette. Ennek ára a jogi képzés feladása volt. Az első érettségi vizsgát 1861/62-ben tartották. Az oktatás fokozatosan magyar nyelvűvé vált, de még az 1870-es években is használták a német nyelvet a tanórákon. ${ }^{14} \mathrm{~A}$ tanulók anyanyelvéhez igazodva viszont négy különböző nyelvű önképzőkör is működött falai közt: német, magyar, szlovák és szerb. Utóbbi szűnt meg először, még az 1850-as években, a szerb anyanyelvü diákok elmaradása miatt, aztán a szlovák az 1870-es években. Szlovák nyelvet azonban 1900/01-ig választható tárgyként még lehetett tanulni. A XVIII. század végén alapított, s azóta majdhogynem folyamatosan múködő német önképzőkör 1894-ben olvadt össze a Magyar Társasággal báró Eötvös Loránd miniszter kezdeményezésére. Eötvös szerint ugyanis egy iskolában két azonos célú önképzőkör működtetetése tanulmányi okokból helytelen. Az így megalakult Lyceumi Ifjúsági Önképzőkörben két nyelven, egy magyar- és egy némettanár vezetésével folyt a munka. ${ }^{15}$

1882-ben a teológiai tagozat önállóvá vált, akadémiává szerveződött. (Belőle alakult ki utóbb az egyetem teológiai kara.) A líceum nevet a gimnázium tartotta meg.

\footnotetext{
12 MÉSZÁros 1988, 242.

13 Valószínűleg a dualizmus korában lett egyházkerületi iskola.

14 Plachy - Pirchala 1904. http://mek.oszk.hu/09500/09536/html/0017/19.html; FUKÁRI 2003, 19-26., 72.; MÉSZÁros 1988, 241-242.

15 MARKuSOVSZKY 1896, 591-602.; FUKÁRI 2003, 33.; Értesítő 1900/01. 138.
} 
A középiskolai törvény elfogadását (1883) követően a fenntartó egy ideig önerőből próbálta fejleszteni az intézményt. A követelményeknek való megfelelés kényszere miatt azonban végül úgy döntött, hogy az állam segítségét kéri. 1895-ben létrejött a szerződés a vallás- és közoktatásügyi miniszter és az iskola vezetése közt: a gimnázium fenntartási államsegélyben, valamint építkezési segélyben részesült. Helyszúke miatt ugyanis új otthon (lásd 3. kép) felépítése vált szükségessé. Ebbe 1896-ban költözhettek át, az új tanév már itt kezdődött. (A gimnázium régi épületét a teológia kapta meg.)

3. kép. A pozsonyi evangélikus főgimnázium új épülete

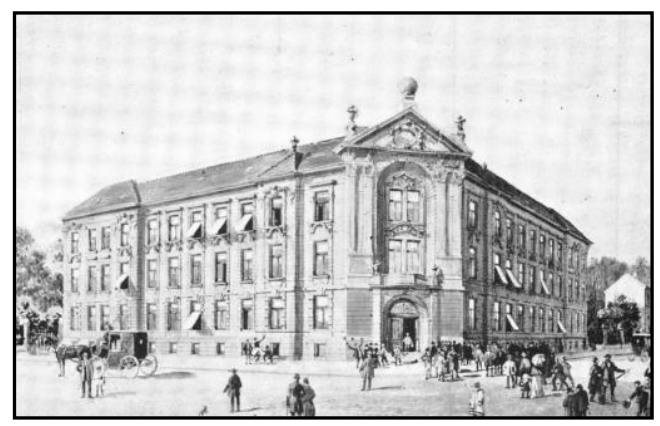

Forrás: Értesitón 1900/01., oldalszám nélkeill (o. n.)

Az építkezés hamarosan folytatódott, 1901-re elkészült az új, 120 férőhelyes internátus (lásd 4. kép), amely a gimnázium épületével szemben állt. Így a korábbinál jóval több diákot tudott az intézmény elszállásolni. Az alumneumban csak kevés hely volt ugyanis. A líceum igen jelentős és egyben értékes könyvtárral rendelkezett. Bél Mátyás több eredeti kéziratát ơrizte. A gimnázium tulajdonában országos viszonylatban is ritka érem- és régiséggyüjtemény állt, amelyet 1897 januárjában konventi határozattal a nyilvánosság számára is látogathatóvá tettek. ${ }^{16} \mathrm{~A}$ gyújteményt Schimko Frigyes Dániel, a líceum egykori növendéke, a bécsi egyetem Protestáns Theológiai Intézetének tanára adományozta a pozsonyi evangélikus egyháznak. ${ }^{17}$

A gimnáziumnak számos kiemelkedő tanára volt a vizsgált korszakban. Itt dolgozott - időrendben - Lichner Pál klasszika-filológus, Lehr Zsigmond múfordító, Kámory Sámuel orientalista, bibliafordító, Böhm Károly filozófus, Schneller István neveléstudós és Kvacsala János teológus, egyháztörténész. ${ }^{18}$

\footnotetext{
16 A régiséggyűjteményről lásd Értesítő 1903/04. 82-83.

${ }^{17}$ Schimkó életéről lásd Schimkó. In SzINNYEI é. n.

http://mek.oszk.hu/03600/03630/html/s/s23014.htm.

18 Plachy - PirChala 1904. http://mek.oszk.hu/09500/09536/html/0017/19.html.; FuKÁRi 2003, 27-83.; MARKUSOVSZKY 1896, 549., 557-558., 609-610., 618-619.
} 
4. kép. A pozsonyi evangélikus fögimnázium internátusa

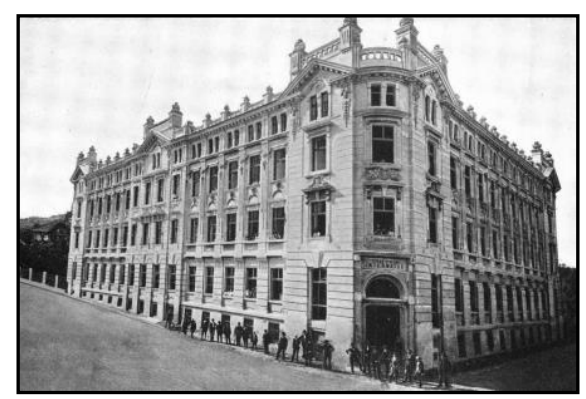

Forrás: Értesitô" 1900/01., o. n.

\section{Az iskola tanulói}

Az iskola népessége a dualizmus korában - ha ingadozásokkal tarkítva is - jelentősen megnövekedett: míg 1867/68-ban 432 volt a beiratkozott tanulók száma, addig 1917/18-ban már 561 (lásd 1. ábra). A növekedés azonban nem volt egyenletes, két nagy hullámvölgy rajzolódik ki. Az egyik mélypontja 1875/76. (312), a másiké pedig 1888/89. (293). Rövid visszaesés figyelhető meg továbbá az első világháború kitörésekor. Feltételezésünk szerint az első apályban közrejátszhatott a helyi reáliskola érettségit adó középiskolává válása. Ugyanekkor ugyanis hasonlóan lecsökkent a királyi katolikus főgimnáziumba járók száma is. A másodikra egyelőre nem találunk magyarázatot. A királyi katolikus főgimnázium tanulóinak száma - az értesítők tanúbizonysága alapján - az 1880-as évek első felében szintén mérséklődött, de ez a tendencia csak néhány évig tartott. Az evangélikus líceumban a 1894/95-ben meginduló növekedést lehetôvé tette az iskola elköltözése: 1896/97-től már volt hely párhuzamos osztály(ok)nak.

Vajon mely vallásfelekezet tagjai voltak az iskola tanulói? Megfigyelhető-e a városra jellemzô heterogenitás vagy a fenntartó felekezet dominanciája állapítható meg? Az adatok alapján (lásd 3. ábra) megállapíthattuk, hogy a legnépesebb csoport az evangélikus vallású diákoké volt. Arányuk mindvégig 50\% körül mozgott. Legmagasabb az 1880-as években volt, amikor majdnem elérte a 60\%-ot. Más evangélikus gimnáziumoktól eltérően ${ }^{19}$ ebben az iskolában nem került kisebbségi helyzetbe az iskolafenntartó felekezet. Az izraelita vallású diákok száma mindazonáltal ebben az intézményben is jelentősen megnövekedett. 1890/91-ben arányuk már 13\%, s ezt követően - a vizsgált tanévekben - mind magasabb: 1915/16-ban már 30\% volt. Ezzel szemben a görögkeleti vallású tanulók száma már a korszak elején igen leesett, s mindvégig nagyon alacsony maradt. Némi ingadozással, de a református vallásúak aránya is csökkent: a kezdeti 23\%-kal szemben az utolsó vizsgált tanévben arányuk

\footnotetext{
${ }^{19}$ Eddig három másik iskolával foglalkoztunk (eperjesi, nyíregyházi, budapesti), ezek mindegyikére igaz ez az állítás: az evangélikus helyett mind a három esetben a legnépesebb felekezeti csoport az izraelitáké lett.
} 
már csak 9\% volt. A katolikus felekezetűek aránya a 11-18\% közti sávban hullámzott.

1. ábra. Tanulói létszám a pozsonyi evangélikus fögimnáziumban $(1867 / 68-1917 / 18$.

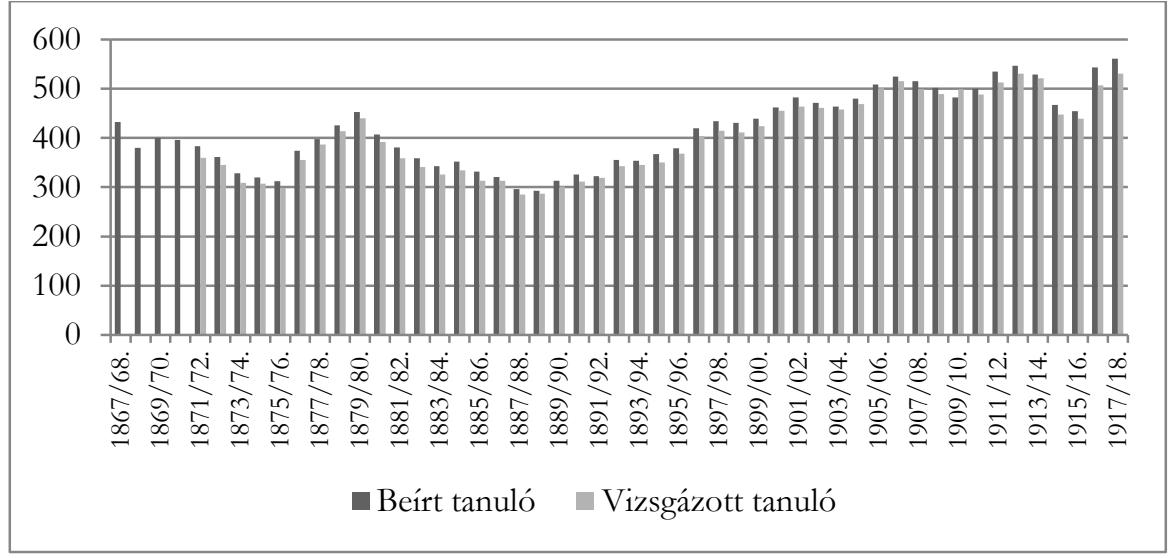

Forrás: Értesitö 1867/68-1917/18.

2. ábra. A tanulók vallásfelekezeti megoszlása tíz kiválasztott tanévben²0

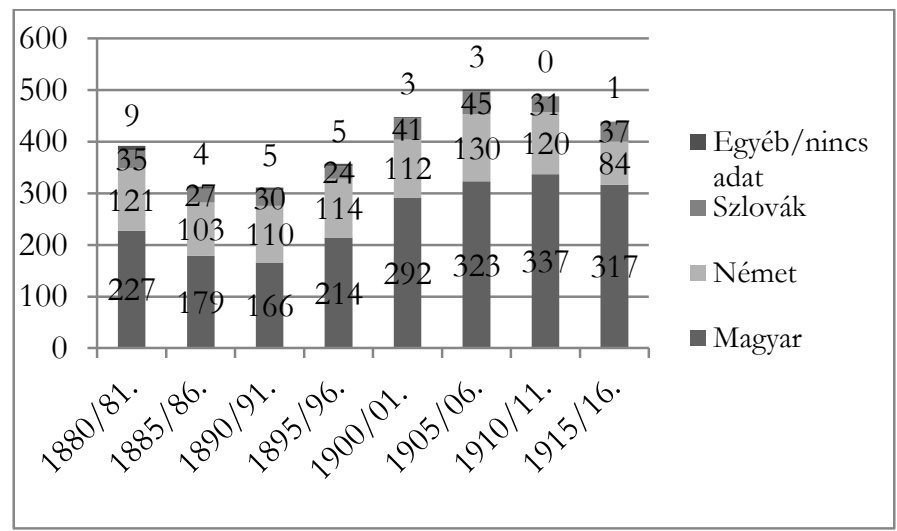

Forrás: Értesitô"1871/72. 43-44., 1875/76. 35, 1880/81. 74., 1885/86. 141., 1890/91. 125., 1895/96. 115., 1900/01. 137., 1905/06. 108., 1910/11. 104., 1915/16. 112.

${ }^{20}$ Az 1870/71. évi értesítő nem tartalmaz adatokat a diákok felekezetére vonatkozóan. Az ábrán az első két tanév kivételével a vizsgázott tanulók felekezeti hovatartozása látható. Két tanév esetén (1895/96. és 1900/01.) az adatsor hiányos. 
A városban és a környező megyékben élő evangélikus felekezetű hívek többségükben német vagy szlovák anyanyelvűek voltak. Feltehetjük a kérdést, vajon a Pozsonyban meginduló asszimiláció és a gimnázium magyar tanítási nyelvűvé válása tükröződött-e vajon a diákok anyanyelvén? Ahogy a 4. ábra mutatja, az anyanyelvet illetően a legnépesebb csoport a magyaroké volt. Arányuk az 1890-es években kezdett növekedni, s 1915/16-ra elérte a 72\%-ot. A német anyanyelvűek eleinte - pontosabban az első négy vizsgált tanévben - a vizsgázottaknak 30-35\%-át tették ki, majd ez a szám lecsökkent 25\% körülire. Az utolsó tanévben viszont már csak 19\% volt. A szlovák anyanyelvüek aránya ugyanakkor hullámzott (6-9\%), nem lehet semmiféle tendenciáról beszélni. Az egyéb (francia, olasz, szerb, román) nyelvűek száma minimális volt.

3. ábra. A vizsgázott tanulók ${ }^{21}$ anyanyelve

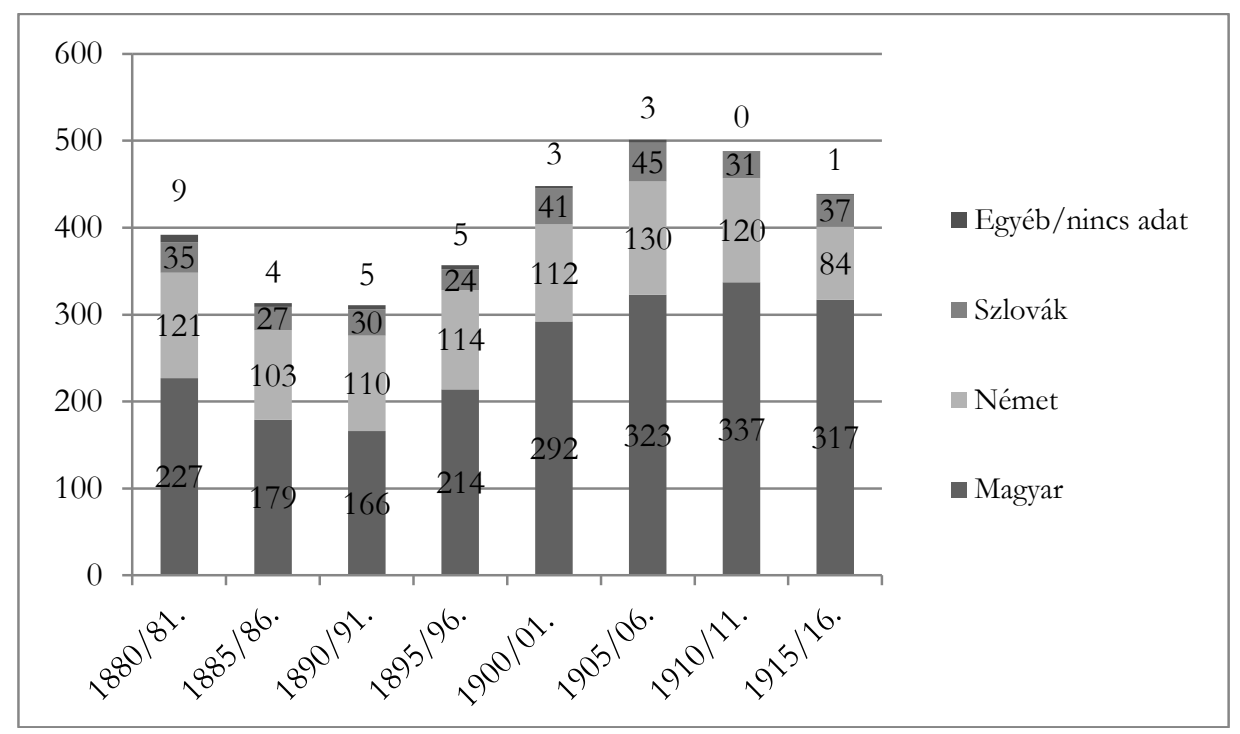

Forrás: Értesitó 1880/81. 74., 1885/86. 141., 1890/91. 126., 1895/96. 115., 1900/05. 137., 1905/06. 108., 1910/11. 104., 1915/16. 112.

A dualizmus időszakában a diákok közt egyre többen voltak pozsonyi lakosok (lásd 5. ábra). (Míg arányuk 1885/86-ban még csak 24\%, 1900/01-ben pedig 34\% volt, addig 1910/11-ben már 47\%, sôt 1915/16-ban már 61\% volt!). Párhuzamosan a Pozsony vármegyéből és más magyarországi vármegyékből érkezők száma lecsökkent. Történt mindez annak ellenére, hogy az iskola férőhelye 1896-tól az átköltözésnek köszönhetően megnőtt, sőt 1901-től nagy, 120 férôhelyes internátus is rendelkezésére állt a távolabb lakóknak. Ezzel a lehetőséggel éltek is: 1905/06-ban 122

21 Két tanév esetén (1895/96. és 1900/01.) az adatok csak a nyilvános tanulókra vonatkoznak. Az 1870/71-es és az 1875/76-os tanévről nincs adat. 
lakója volt, öt évre rá 117, 1913/14-ben pedig 122, aztán évekig nem használhatták, ${ }^{22}$ ugyanis 1914/15-ben katonai kórház céljára lefoglalták. ${ }^{23}$ A távolabb lakók elmaradásában minden bizonnyal szerepet játszott a magyarországi középiskolai hálózat bővülése, illetve a korábban négy- vagy hatosztályos intézmények érettségit adó iskolákká fejlesztése.

\section{4. ábra. A tanulók ${ }^{24}$ szüleinek állandó lakhelye}

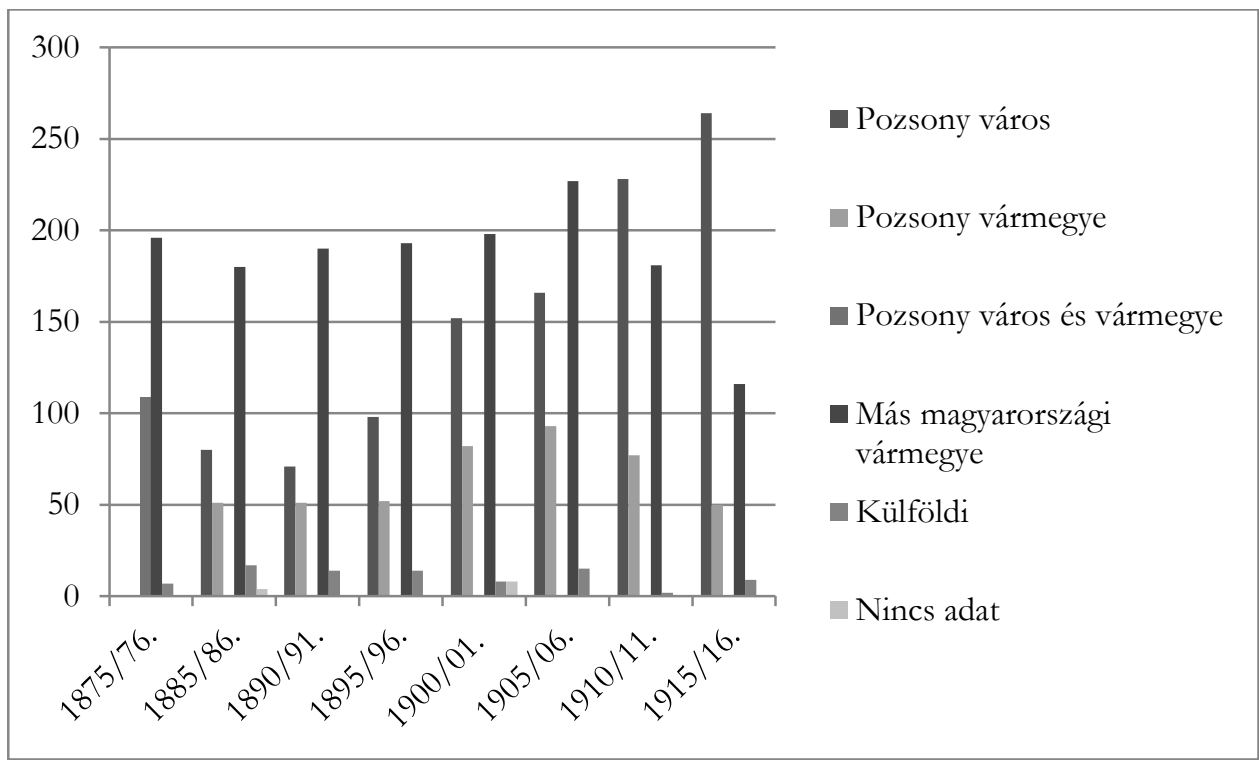

Forrás: Értesitó 1875/76. 35., 1885/86. 140., 1890/91. 125., 1895/96. 116., 1900/01. 138., 1905/06. 108., 1910/11. 103., 1915/16. 111.

Három tanév esetén pontos ismereteink vannak arról, mely vármegyékből érkeztek az iskola növendékei. Ez alapján a beiskolázási körzetet - Pozsony város és vármegye mellett - elsődlegesen a szomszéd vármegyék (Sopron, Győr, Moson, Komárom, Nyitra, Bars, Trencsén) alkották. A beiratkozott diákok 33-34\%-a lakott ezekben. A legtöbben mind a három tanévben Nyitrából érkeztek, a második helyen pedig Komárom állt. Viszonylag sokan iratkoztak be egyes távolabb fekvő vármegyékbőll (Pest-Pilis-Solt-Kiskun, Bács-Bodrog vagy Trontál). Ez azért is feltúnő,

\footnotetext{
22 Értesítő 1905/06, 109.; Értesítő 1910/11, 105.; Értesítő 1913/14, 116.

${ }^{23}$ Értesítô 1914/15, 41.

${ }^{24} \mathrm{Az}$ első három tanév esetén az adatok a beiratkozott tanulókra vonatkoznak, a többi esetben pedig a vizsgázottakra. Az 1895/96-os és az 1900/01-es tanév esetén csak a nyilvános tanulók lakóhelyét tüntették fel. Az 1875/76-os tanévi értesítőben nem különítették el Pozsony várost Pozsony vármegyétől. 1880/81-ről nincs adatunk.
} 
mert több dunántúli vármegye ${ }^{25}$ viszont igen alulreprezentált volt. Mindig többen érkeztek Felső- és Nyugat-Magyarország egyéb vármegyéiből is. Erdélyi, kelet-alföldi vármegyék azonban nem vagy csak elvétve szerepeltek a listán. ${ }^{26}$

$\mathrm{Az}$ alábbiakban az iskola arisztokrata tanulóira fókuszálunk. Bemutatjuk ezt a csoportot, s megvizsgáljuk, vajon jellemzőiben eltért-e a teljes tanulóifjúságtól. S mivel az arisztokrácia származás, felekezet, vagyon s egyéb tényezők szerint differenciálódott, s egységesnek ezért nem is nevezhető, néhány családdal kiemelten foglalkozunk. ${ }^{27}$

\section{Arisztokrata diákok az iskolában}

A dualizmus korában - az értesítők tanúsága szerint - 55 főnemesi ranggal bíró diák tanult az intézményben. Számuk alakulása nem követte az összes tanulóét, annak ellenére, hogy többségük - ahogy látni fogjuk - nyilvános tanuló volt: a csúcs 1877/78-ben volt (13 fő), az 1880-as évek második felétól csak néhány fővel voltak jelen, a századfordulón kissé megnôtt a számuk, majd szinte teljesen elmaradtak. 1905/06-tól csak négy tanévben találkozhatunk velük a névsorban, s akkor is mindössze 1-1 fővel (lásd 2. ábra). Egy részük a helyi királyi katolikus főgimnáziumot választhatta, ahol számuk éppen ezidőtájt növekedett meg. ${ }^{28}$

5. ábra. A pozsonyi evangélikus főgimnázium arisztokrata tanulói (fő)

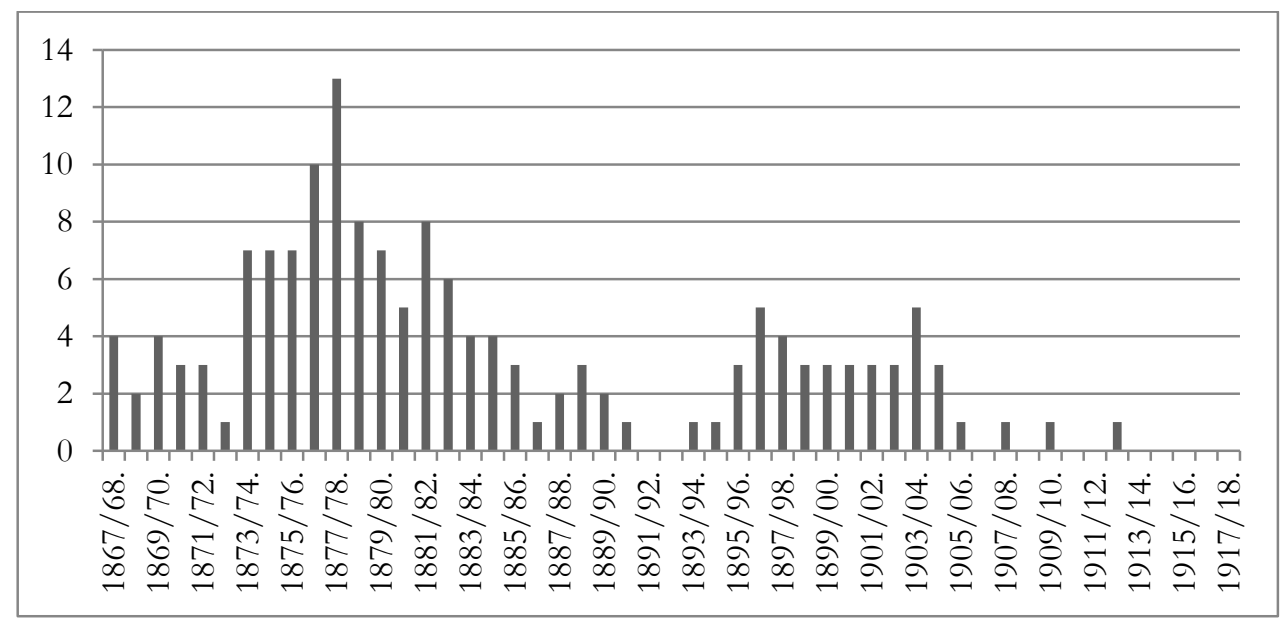

Forrás: Értesitón 1867/68-1917/18.

\footnotetext{
${ }^{25}$ Somogy, Zala, Tolna, Baranya, Fejér.

${ }^{26}$ Értesítő 1875/76, 35.; Értesítő 1885/86, 140.; Értesítő 1890/91, 125.

27 Vö. BALLABÁs 2013, 37-49.

28 RÉBAY 2015, 253-254.
} 
A főnemesi ranggal rendelkező 55 diák 29 családból érkezett, ezek közül 11 a grófi, 18 pedig a bárói címet viselte. Közülük a legtöbb diákot a báró Buttler és a báró Podmaniczky család adta, 6-6 fôt. A báró Buttler család valamennyi ismert iskolás fiú tagja a korszakunkban ennek az intézménynek (is) a diákja volt: báró Buttler Henriknek (1827-1910), aki Nógrád vármegye szolgabírája volt, három fia (Ervin, Jenô, László29) és két unokája (Elemér és ifj. Ervin $\left.{ }^{30}\right)$, testvérének, Frigyesnek (18281910) egyetlen fia (Sándor $\left.{ }^{31}\right){ }^{32}$ Mind a hatan az iskola nyilvános tanulói voltak. Egyikőjük sem végezte el itt valamennyi gimnáziumi osztályt. A legfiatalabbakról tudjuk, hogy középiskolai tanulmányaikat (I-II. osztály) a budapesti evangélikus gimnáziumban kezdték meg egyidőben,

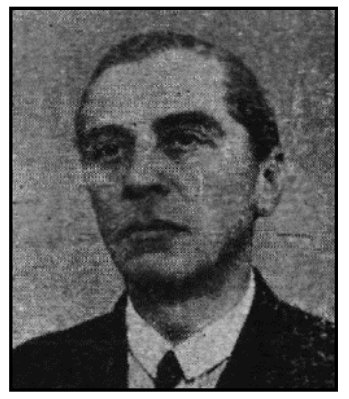

5. kép. Báró Buttler Elemér

Forrás: Haeffler szerk. 1940, 144. mégpedig magántanulóként. A III. osztályt egy másik helyen végezték el, s ezt követően jelentkeztek a pozsonyi gimnáziumba - a IV. osztályba - immár nyilvános tanulónak. Két évet töltöttek el itt, majd megint egy másik iskolába iratkoztak be. ${ }^{33}$ Elemér (lásd 5. kép) később a budapesti tudományegyetemen folytatott jogi tanulmányokat, s államtudományból doktorált. (Öccsének is jogi doktorátusa volt.) Ezt követően a családi birtokon gazdálkodott. 1939-ben Balassagyarmat országgyülési képviselőjévé választották.34

A szintén evangélikus Podmaniczky családból 35 is hat fiút írattak be a pozsonyi evangélikus gimnáziumba. (A család erősen kötődött ${ }^{36}$ az aszódi evangélikus gimnáziumhoz is, amely azonban sokáig algimnázium volt, csak 1915/16-ban nyílt meg a VIII. osztálya. Feltehetően ezért nem is jártak oda a fiúk.) A Podmaniczky diákok is több generációból kerültek ki. Báró Podmaniczky Árminnak (1825-1886), báró Podmaniczky Frigyes, a híres politikus öccsének, mindkét feleségétől született valamennyi fia (Elemér, Béla, Gyula, Endre, Pál) ${ }^{37}$ az iskola tanulója volt - de csak

\footnotetext{
${ }^{29}$ Báró Buttler Ervin (1857-1927), báró Buttler Jenő (született Libercsén 1865 körül, Gudenus adatai az értesítójével nem egyeznek), báró Buttler László (1867-1909).

30 Báró Buttler Elemér (1889-1970), báró Buttler Ervin (1890-1975).

${ }^{31}$ Báró Buttler Sándor (1865-1942).

32 Gudenus 1999b, 53-56.

33 Értesítő Budapest 1900/01. 51., Értesítő Budapest 1901/02. 53., Értesítő 1903/04. 109., Értesítő 1904/05. 89. A tanulmányi utak feltérképezéséhez a Hungaricana közgyűjteményi portál iskolai értesítő adatbázisát (https://library.hungaricana.hu/hu/search/) használtuk, ebben azonban a középiskoláknak csak egy hányada szerepel.

${ }^{34}$ HAEFFLER szerk. 1940, 27.; 144-145.; GudENus 1999b, 54.

35 A család történetét a XVI. századig bezárólag feldolgozta Lukinich (1943).

${ }^{36}$ Ennek oka, hogy báró Podmaniczky Árminnak itt volt birtoka. Annak eladása után is segítették azonban a család tagjai az iskolát. (Lásd PeTRY 1900, 3-49.)

${ }^{37}$ Báró Podmaniczky Elemér (1852-1909), báró Podmaniczky Béla (1853-1912) alezredes, a mezőhegyesi királyi ménes parancsnoka, báró Podmaniczky Gyula (1855-1920) huszárőrnagy, helyettes államtitkár, báró Podmaniczky Endre (1858-1932) huszárőrnagy, nemzetgyủlési képviselő és báró Podmaniczky Pál (1885-1949) teológiai professzor.
} 
viszonylag rövid ideig. Szokatlan a legkisebb, Pál iskolai pályája, aki jóval fiatalabb volt bátyjainál..$^{38}$ Egy éves korában elvesztette koronauradalmi igazgatóként dolgozó atyját, majd sorsa hamarosan rosszra fordult, vagyonából kiforgatták. Ugyan kitűnő képességei voltak, a középiskolából anyagi okokból két év után kimaradt. Tanulmányait magánszorgalomból, önállóan folytatta. 1903-ban érettségi bizonyítvány hiányában rendkívüli hallgatóként kezdhette csak meg az evangélikus lelkészképzést Pozsonyban. A hiányt pótlandó ugyanekkor az itteni evangélikus gimnáziumban magánvizsgát tett a IV. és az V. osztály anyagából, majd a következő évben újra kétkét osztályéból. ${ }^{39}$ Erre ekkoriban miniszteri engedéllyel lehetőség nyilt. 21 évesen, 1906-ban érettségizett le, egy évre rá pedig diplomát szerzett. Ezt követően egy évig a rostocki egyetemen tanult, majd lelkészként dolgozott. 1910-ben anyaintézményében magántanári képesítést szerzett. 1917-től előbb az eperjesi, egy évre rá a pozsonyi teológiai akadémia/kar tanára lett. ${ }^{40}$

A család másik ágából egyetlen gyermeket írattak be a pozsonyi evangélikus gimnáziumba, Horácot (1866-1938). ${ }^{41}$ Vele hatéves korától magántanárok foglalkoztak. 1875/76-ban a budapesti evangélikus elemi iskola tanulója lett. A következó évben iratkozott be a pozsonyi evangélikus gimnáziumba, ahol nyilvános tanulóként négy évet töltött. Ekkor családja is Pozsonyban élt. A fơvárosban, a piaristáknál érettségizett 1884-ben. Majd a budapesti egyetem jogi karán folytatta tanulmányait. 1887ben néhány hónapot rendkívüli hallgatóként a Sorbonne-on töltött. Jogi diplomát 1888-ban Budapesten szerzett. Külföldi tanulmányutakra később is vállalkozott: először a korszerű gazdálkodást figyelte meg, később, mikor már eladta birtokát, könyvtártudományi ismereteit gyarapította. Jelentős szakmai karriert futott be: dolgozott a Központi Statisztikai Hivatalban, a római Nemzetközi Mezőgazdasági Intézet könyvtárának igazgatójaként is ténykedett, végül a Pénzügyminisztérium miniszteri tanácsosaként ment nyugdíjba. ${ }^{42}$

Egy másik evangélikus családnak, a gróf Zaynak öt tagja járt a pozsonyi evangélikus gimnáziumba. Ez a család is erősen kötődött az evangélikus egyházhoz. Gróf Zay Károlynak (1797-1871), az evangélikus egyház egyetemes felügyelójének ${ }^{43}$ unokái és dédunokája voltak az iskola tanulói. Esetükben is szoros rokoni kapcsolat mutatható ki tehát. Károly fia, gróf Zay Albert (1825-1904) a bécsújhelyi akadémia mérnöki karán folytatott tanulmányait követően katonai pályára lépett. Ennek lezárását követően átvette apja birtokát és posztógyárát, majd faipari vállalkozásaiból nagy vagyonra tett szert. Cenzus alapján tagja lett a Főrendiháznak. 1887-ben és 1892-ben pedig a baáni kerület (Trencsén vármegye) szabadelvű párti képviselőjévé

\footnotetext{
38 GUdENUS 1999a, 97-105.

39 Ugyan az 1904/05. évi értesítóben csak a VI. osztály tanulói közt szerepel, minden bizonnyal az V. osztály anyagából is itt vizsgázott le. (Értesítő 1903/04. 109., 111.; Értesítő 1904/05. 92.; Értesítő 1905/06. 106-107.)

40 Podmaniczky Pál története, 2015. http://cultura.hu/kultura/podmaniczky-pal-tortenete/

${ }^{41}$ Gudenus 1999a, 96.

42 RózSA főszerk. 2014, 585.

${ }^{43}$ Életét bemutatja: FUKÁRI 2008, 117-132.
} 
választották. Ezután újra a Főrendiház névsorában szerepelt, mint örökös tag. ${ }^{44} \mathrm{Ki}$ lenc gyermeke született, s mind a négy fia (Miklós, László, Imre, Károly ${ }^{45}$ ) az általunk vizsgált iskola tanulója lett. Az országos politikai közéletben egyedül a legidősebb gyermeke vett részt. Miklós három középiskolában is megfordult. Az algimnáziumi osztályok tananyagából ${ }^{46}$ Pozsonyban tett magánvizsgát. A felsőbb osztályokat már nyilvános tanulóként végezte el: először két évig a selmecbányai evangélikus gimnáziumban, aztán egy évig a budapesti evangélikus gimnáziumban, végül ismét a selmecbányai iskolában. Itt is érettségizett jeles eredménnyel. ${ }^{47}$ Ezt követően Genfben modern idegen nyelveket és kereskedelmet tanult, majd Párizsban és Budapesten jogot. Külföldi útjain szerzett benyomásait, tapasztalatait publikálta. 1888-ban tagja lett a Főrendiháznak. Az egyházi közéletbe is bekapcsolódott: 1890-ben az orosházi református egyházközség világi felügyelője lett. 1896-ban ugyanitt a szabadelvú párt színeiben országgyúlési képviselővé választották. ${ }^{48} 1901$ ben veszített, mivel azonban elmebetegség miatt gondnokság alá helyezték, a Főrendiházban sem politizálhatott többé. ${ }^{49}$

Miklós fia, Károly Albert ${ }^{50}$ tanulmányi pályáját nem sikerült teljes mértékben rekonstruálni; annyit tudunk, hogy a II-IV. osztályt magántanulóként végezte el Pozsonyban. ${ }^{51}$ Miklós testvéreiről viszont kiderült, hogy ők is megfordultak a pozsonyi mellett a selmecbányai evangélikus gimnáziumban. Gróf Zay László ugyanis szintén Pozsonyban kezdte tanulmányait magánúton (I. osztály), majd Selmecbányán folytatta, még mindig magántanulóként (a II. osztályba kétszer iratkozott be). A III. osztályt már Budapesten járta ki nyilvános tanulóként. Ezt követően azonban nem tért vissza Selmecbányára, mint a bátyja és az öccse, hanem Pozsonyban lett nyilvános tanuló (IV-VIII. osztály). ${ }^{52}$ Gróf Zay Imre már Selmecbányán kezdte gimnáziumi tanulmányait szintén magántanulóként. Ekkor a testvérei is itt tanultak. Ugyanakkor, amikor a többiek, ő is váltott, s hozzájuk hasonlóan Budapesten lett nyilvános tanuló (II. o.). Aztán visszatért Selmecbányára immár mint rendes tanuló (IV. o.), majd egy évet Pozsonyban végzett el. Ezt követőn viszont egy negyedik, általunk ismeretlen iskolában tanult (V-VI. o.), az utolsó két évben viszont újra a pozsonyi

\footnotetext{
${ }^{44}$ HALÁSZ szerk. 1887, 176.; STURM szerk. 1892, 349.; STURM szerk. 1901, 114.

45 Gróf Zay Miklós (1864-1939), gróf Zay László (1866-1925), gróf Zay Imre (1867-1941), gróf Zay Károly (1872-n.a.)

46 Igazolhatóan az I., a II. és a IV. osztályt, viszont nagy valószínűséggel a III. osztályt is. (Értesítő 1874/75. 26.; Értesítő 1875/76. 27.; Értesítő 1876/77. 26.)

47 Értesítő Selmecbánya ev. 1877/78. 5.; Értesítő Selmecbánya ev. 1878/79. 3.; Értesítő Budapest 1879/80. 53.; Értesítő Selmecbánya ev. 1880/81. 30., 53.

48 STURM szerk. 1897, 380-381.

${ }^{49}$ STURM szerk. 1901, 115.; Az 1906. évi május hó... I., 1906, 24. sz. 38.

${ }^{50}$ Gróf Zay Károly Albert (1890-1941).

51 Értesítő 1901/02. 159.; Értesítő 1902/03. 93.; Értesítő 1903/04. 111.

52 Értesítő 1876/77. 26., Értesítő Selmecbánya ev. 1877/78. 4.; Értesítő Selmecbánya ev. 1878/79. 2.; Értesítő Budapest 1879/80. 50.; Értesítő 1880/81. 59.; Értesítő 1881/82. 54.; Értesítő 1882/83. 35.; Értesítő 1883/84. 59.; Értesítő 1884/85. 115.
} 
evangélikus gimnázium diákja lett. ${ }^{53}$ A négy testvérből a legfiatalabb, Károly csak két évig volt beiratkozva - magántanulóként - ebbe az iskolába, mindkétszer az I. osztályba. ${ }^{54}$

Izgalmas lenne tudni az iskolaváltások okait. A(z esetleges) rossz tanulmányi eredmény ugyanis csak az egyik lehetséges magyarázat. ${ }^{55}$ A család valószínűsíthetően ebben az időszakban Zayugrócon lakott, tehát a költözés sem lehet indok. Amint láthattuk, a gyermekek többé-kevésbé egyszerre mozogtak. Ahogy az eltérés okaira, úgy általában az iskolaválasztás mögött meghúzódó szándékokra azonban csak személyes forrásokból lehetne következtetni. ${ }^{56}$

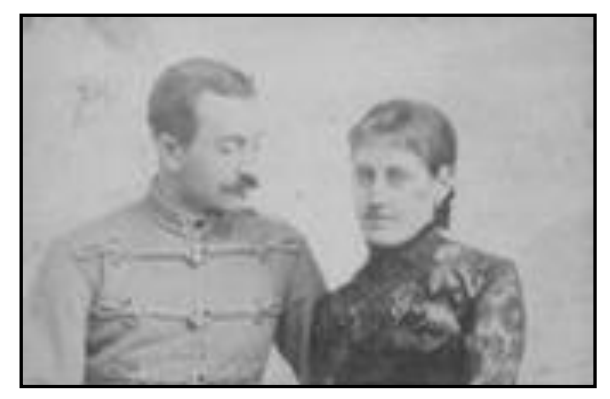

6. kép. Báró Marschall Gyula

Forrás: Gyula Marchall. bttps:/ / www.geni.com/people/GyulaMarschall/6000000013238577860.

A családok közt nagyságrendben a negyedik, a báró Marschall is evangélikus volt. A thüringiai Altengotternben született báró Marschall Levin (1824-1894) cs. és kir. lovaskapitány, Thüringia örökös tartományi marsallja magyar hölgyet vett feleségül. A Nógrád megyei Bercelen vásárolt kastélyt és birtokot. Mindkét gyermeke, Julian/Gyula (1858-1932) és Rudolf (1863-1903) tanult a pozsonyi evangélikus gimnáziumban. ${ }^{57}$ Julian 1869/70-ben tűnt fel a névsorban a IV. osztály nyilvános tanulói közt. A következő évben ugyanitt ismételte meg a IV. osztályt, továbbra is nyilvános tanulóként. Rudolf 1873/74-ben az I. osztályba iratkozott be szintén rendes tanulóként. ${ }^{58}$ Egyikük további tanulmányi útja sem ismert. Gyula (lásd 6. kép) a katonai pályát választotta, az altábornagyi rangig jutott, s számos magas kitüntetést szerzett. ${ }^{59}$

A báró Marschall család másik két, Pozsonyban tanuló tagja ${ }^{60}$ közül Werner 1871-ben született a Komárom vármegyei Ácson. Az ő középiskolai tanulmányi útja jól nyomon követhetô. A közeli rév-komáromi bencés algimnáziumban végezte 1882/83-ban az I. osztályt magántanulóként Kolpaszky Pál vezetésével. A következő tanévtől kezdve öt éven keresztül a győri bencés gimnáziumba járt. Az utolsó

\footnotetext{
53 Értesítő Selmecbánya ev. 1878/79. 3.; Értesítő Budapest 1879/80. 50.; Értesítő Selmecbánya ev. 1880/81. 35.; Értesítő 1881/82. 52.; Értesítő 1884/85. 115.; Értesítő 1885/86. 139.

${ }^{54}$ Értesítő 1882/83. 30.; Értesítő 1883/84. 51. Hogy hová iratkozott be ezt követően, az nem ismert. A Hungaricana portál adatbázisa alapján sem a budapesti, sem a selmecbányai evangélikus gimnáziumba nem járt.

$55 \mathrm{Az}$ említett evangélikus gimnáziumok nem közlik a tanulmányi eredményt.

56 A Zay család Szlovák Nemzeti Levéltárban (Pozsony) őrzött iratainak kutatására nem nyílt lehetőségünk.

57 GUDENUS 1993, 282-283.

${ }^{58}$ Értesítő 1869/70. 22.; Értesítő 1870/71. 15.; Értesítő 1873/74. 22.

${ }^{59}$ MTI, Napi hírek 1932. június 4/6. kiadás. https://library.hungaricana.hu/hu/view/NapiHirek_1932_06_1/?query=SZO $\% 3 \mathrm{D}(\% 22$ marschall $\% 20$ gyula $\% 22) \& p g=119 \&$ layout $=\mathrm{s}$.

60 Ōk valószínúleg nem báró Marschall Levin gyermekei, a genealógiákban nem szerepelnek.
} 
két évet - szintén nyilvános tanulóként - a pozsonyi evangélikus gimnáziumban végezte el. VIII. osztályos korában az Önsegélyező Intézet fópénztárosa volt. ${ }^{61}$ Ö is katonai pályára lépett (1891), 1918-ig a császári és királyi haditengerészetnél szolgált, hajókapitány lett. ${ }^{62}$

Báró Marschall Ernő 1883-ban született Bercelben ${ }^{63}$, a pozsonyi evangélikus gimnáziumban az I-II. és az V-VIII. osztályt végezte el nyilvános tanulóként. Jó tanulmányi eredményeiért II. osztályos korában jutalomkönyvet kapott. Többször adakozott jótékony vagy társadalmi célra, mint pl. 1899-ben a pozsonyi Petőfi szobor felállitására. Jó eredményeket ért el testnevelésből. 1901-ben magasugrásban részt vett az országos ifjúsági tornaversenyen (II. hely), s vívni is tanult az iskolában. ${ }^{64}$ Mégsem követte a családi tradíciókat, nem a katonai hivatás mellett döntött, hanem elvégezte az erdészeti főiskolát és erdőmérnök lett, végül az erdőtanácsosi címig jutott. 1946-ban háborús és népellenes bűntettért letartóztatták, 1950-ben szabadult. ${ }^{65}$

Egy másik idegen eredetű (frank) családnak, a báró Feilitzschnek is több tagja megfordult a pozsonyi evangélikus gimnáziumban: báró Feilitzsch Fedor Lázár (1823-1883) három fiatalabb fiúgyermeke. ${ }^{66}$ Közülük a legkisebb, a magyar politikai és társadalmi élet befolyásos alakjává vált Berthold (1867-1949) így emlékezett viszsza gyökereire és iskolás éveire: „Anyám, Lukáts Friderika nemes katonacsaládból sqármazott. [...] Édesatyám, Feilitzssch Feodor Lázár báró, öseinek többsæáąéves kastélyában, Kürbitzben született a szász királyságban.... [...] Atyám a katonai pályára lépett és 1843-1845ig mint hadnagy a porosz királyi I. Gárda-dzsidás ezredben szolgált. Mint abban az idóben nagyon sok kïlföldi, ố is átlépett az os:trák hadseregbe... Hires lovas, kiváló lóismerö és nagyon gyakorlott kardvivó volt. Nyelvtehetsége nem volt, a magyar nyelvet elsajátitani nem tudta. De szigorían örködött felette, hogy fiai magyar iskolákban és magyar szellemben neveltessenek. Igy én is Pozsonyban - abol családunk letelepedett - nöttem, fel, ott végeztem a középiskolát az evangélikus liceumban, a jogot is Pozsonyban hallgattam és ott szereztem meg az államtudományi államvizsgáról a bizonyitványt is. Akkori idóben még nem volt divatban a doktori fokozat elnyerése.’67 Neveltetéséről szólva hozzátette: „... nem mulaszthatom el megemlékęni

${ }^{61}$ Értesítő Komárom 1882/83. 44.; Értesítő Győr 1883/84. 226.; Értesítő Győr 1884/85. 197.; Értesítő Győr 1885/86. 221.; Értesítő Győr 1886/87. 138.; Értesítő Győr 1887/88. 222.; Értesítő 1887/88. 152.; Értesítő 1888/89. 145., 134.

62 Rangliste... 1918, 16.

63 Apja Gyula, anyja Péczy Sarolta. (HU BFL - VII.101.d - rab. VI - 3356. https://archives.hungaricana.hu/hu/lear/Fogoly/38065/.)

${ }^{64}$ Értesítő 1893/94. 142.; Értesítő 1894/95. 235., 242.; Értesítő 1897/98. 95.; Értesítő 1898/99. 111., 140.; Értesítő 1899/00. 68., 97.; 105., 108., 109.; Értesítő 1900/01. 89., 98., 100., 136., 148.

65 Változások... 1917, 454.; HU BFL - VII.101.d - rab. VI - 3356. https://archives.hungaricana.hu/hu/lear/Fogoly/38065/.

${ }^{66}$ Gudenus 1990, 384-386.

${ }^{67}$ Feilitzsch 1933, 4-5. 
Martinengó Nándor68 vivómesteremról, aki nemcsak vivni tanitott meg, hanem lovagias szellemet is oltott belém. Nagy nevelöhatással volt reám a sport is, melynek sok szabad órámat szenteltem. Vivtam - föleg vivótörrel, - korcsolyáztam, evezțem és föleg Nyirregyházán sokat gyakoroltam a tennis:. $\% 9$

Báró Feilitzsch Berthold azon kevesek közé tartozott tehát, akik nem váltottak középiskolát. ${ }^{70}$ Mindvégig nyilvános tanuló volt, s elég aktívan kivette a részét az iskolai közéletben. Könyveket adományozott a magyar és a német önképzőkör könyvtárának, ajándékokkal gazdagította a természetrajzi gyűjteményt, végzősként pedig az Önsegélyező Intézet osztálypénztárnoka volt. ${ }^{71}$ Jogi tanulmányai befejezése után Torontál vármegye közigazgatásában kezdett el dolgozni. 1897-ben az uralkodó Szabolcs vármegye főispánjává nevezte ki. Ezt a tisztséget négy évig töltötte be. 1927-ben Csonka-Bihar vármegye élére került, 1929-től pedig Békés vármegyét is ő vezette. 1930-ban előbbi tisztségéről felmentették, utóbbiról 1931-ben ő mondott le. ${ }^{72}$

Bátyja, Kamill ${ }^{73}$ viszont csak egy esztendőre iratkozott be a pozsonyi evangélikus gimnáziumba, a VII. osztályba. Több iskolában is megfordult: $1874 / 75-$ ben $^{74}$ a selmecbányai királyi katolikus nagygimnázium IV., egy évre rá az V. osztályának nyilvános tanulója volt. A VI. osztályt viszont a nagykanizsai piarista gimnáziumban végezte el, ahol a Segélyező Egylet választmányi tagjaként is szerepet vállalt. Franciául és gyorsírni is tanult. Kamill pozsonyi diákként hunyt el 1877-ben vagy 1878ban. ${ }^{75}$ Testvére, Alfréd (1863-1936) is megfordult ebben a három gimnáziumban: 1875/76-ban Selmecbányán III., 1876/77-ben Nagykanizsán IV. osztályos volt. Testvéréhez hasonlóan mindkét intézményben nyilvános tanuló volt. Majd ő is a pozsonyi evangélikus gimnázium diákja lett. Eredményei alapján az V. osztályt meg kellett ismételnie. A második évben már magántanuló volt. ${ }^{76}$

Az utolsó család, amelynek a tagjaira részletesebben kitérünk, a katolikus vallású Logothetty (Logothetti), amely velencei, később osztrák grófi címet kapott. Három

\footnotetext{
${ }^{68}$ Martinengo Nándor Pozsony neves vívómestere volt, báró Feilitzsch Berthold iskolai tornatanára 1877/78. és 1879/80. között. Feltehetőleg később magánórákat is vett tőle. (Értesítő 1877/78. 30.; Értesítő 1878/79. 38.; Értesítő 1879/80. 5.)

${ }^{69}$ FeILITZSCH 1933, 7.

${ }^{70}$ Értesítő 1877/78. 48., Értesítő 1878/79. 60., Értesítő 1879/80. 30.; Értesítő 1880/81. 58.; Értesítő 1881/82. 53.; Értesítő 1882/83. 34.; Értesítő 1883/84. 58.; Értesítő 1884/85. 115.

${ }^{71}$ Értesítő 1882/83. 12.; Értesítő 1883/84. 47-48.; Értesítő 1884/85. 103.

${ }^{72}$ Feilitzsch 1933, 11-12., 22., 38-41.

${ }^{73}$ Kamil és Camill néven is szerepelt. Született 1860 körül Törökkanizsán (Torontál). (Gudenusnál [1990, 384-386.] nem szerepel.)

${ }^{74}$ Érdekes, hogy a két bátyjuk nem járt ezekbe az iskolákba, hanem Arthur pl. pont 1874/75-ben a szegedi piaristáknál végezte a VII. osztályt nyilvános tanulóként. (Értesítố Szeged 1874/75. 32.) Ugyaninnen maradt ki két évvel korábban - csak a VI. osztályból - Feodor. (Értesítő Szeged 1872/73. 18.)

${ }^{75}$ Értesítő 1877/78. 57.; Értesítő Selmecbánya kat. 1874/75. XIII.; Értesítő Selmecbánya kat. 1875/76. 37.; Értesítő Nagykanizsa 1876/77. 30., 53., 55.

${ }^{76}$ Értesítő Selmecbánya kat. 1875/76. 35.; Értesítő Nagykanizsa 1876/77. 51.; Értesítő 1877/78. 54.; Értesítő 1878/79. 64.
} 
tagja járt a pozsonyi evangélikus gimnáziumba: Hugó, Jenő és Leó. ${ }^{77}$ A legidősebb a IV-VIII. osztályt végezte el itt nyilvános tanulóként, a középső csak a III-IV. osztályt, míg a legfiatalabb az alsó négy osztályt. ${ }^{78}$ (Érdekes, hogy olyan év nem volt, amikor mind a hárman ide jártak volna.) A két idősebb fiú a helyi királyi katolikus főgimnáziumban kezdte gimnáziumi tanulmányait. 1870/71-ben Hugó a II. osztályba iratkozott be, Jenő pedig az elsőbe. Ekkor még magántanulók voltak. A következő tanévben mind a ketten másodikosok és nyilvános tanulók lettek. A rákövetkező évben viszont Jenőnek kellett ismételnie a II. osztályt, Hugó felléphetett a harmadikba. Tanulmányi eredményeik továbbra is meglehetősen rosszak maradtak: 1873/74-ben a rajz mellett egyikük latinból, másikuk magyarból lett elégtelen. ${ }^{79}$ 1874/75-ben már mind a ketten az evangélikus gimnázium tanulói lettek. Későbbi tanulmányaikról, életükről nem rendelkezünk adattal.

\section{6. ábra. Az arisztokrata diákok szülőhelye}

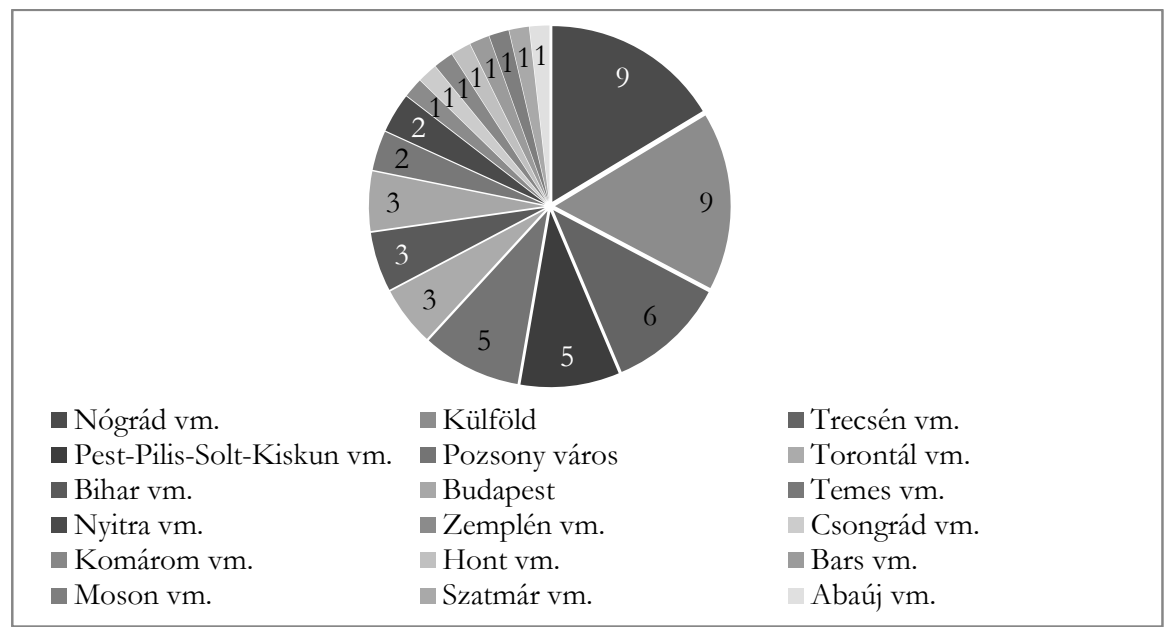

Forrás: Értesitö 1867/68-1917/18.

Az arisztokrata diákok szüleinek állandó lakhelyérôl nem állnak rendelkezésünkre adatok, így az alapsokasággal nem tudunk összehasonlítást tenni. Ismert azonban a születési helyük (lásd 6. ábra). E társadalmi réteg esetén nem meglepetés,

\footnotetext{
77 Ugyan mindegyikük máshol született, de mivel csak néhány év különbséggel, s körülbelül egy időben játak ugyanazokba az iskolákba, feltehetőleg testvérekről van szó. Gudenusnál egyikük sem szerepel (1993, 200-203.) Az értesítők alapján Hugó 1859 körül született Bécsben, Jenő nagyjából egy év múlva Pozsonyban, míg Leó 1865 körül Temesvárott.

${ }^{78}$ Értesítő 1873/74. 23-24.; Értesítő 1874/75. 29-30.; Értesítő 1875/76. 26., 31.; Értesítő 1876/77. 24., 29.; Értesítő 1877/78. 52., 58.; Értesítő 1878/79. 63.

${ }^{79}$ Értesítő Pozsony kat. 1870/71. 56., 58.; Értesítő Pozsony kat. 1871/72. 62.; Értesítő Pozsony kat. 1872/73. 40-41.
} 
hogy mily sokan születtek külföldön. Többen voltak a pozsonyiak is. 1-1 vármegye felülreprezentáltsága hátterében pedig a népesebb családok állnak: pl. a báró Buttler Nógrad vármegye súlyát növelte, Trencsénét pedig a gróf Zay.

Végül megemlítjük azokat az arisztokrata famíliákat, amelyek kettő vagy egy diákot „adtak” a pozsonyi evangélikus gimnáziumnak. Az első csoportba tartozik négy család (báró Boemelburg, báró Leonhardi, báró Mannsberg és a gróf Matuschka), a másodikba pedig húsz (báró Ambrózy, báró Buttlár, báró Clauer, gróf Erdődy, gróf Esterházy, gróf Hardenberg, báró Hoenning, báró Maasburg, gróf Mensdorf-Pouilly, báró Nyáry, báró Papen, gróf Pálffy, gróf Ráday, gróf Schweinitz, báró Török, báró Uray, báró Üchtritz, gróf Vasquez, báró Ward, báró Wildburg).

Az arisztokrata diákok közt - az összes diákhoz hasonlóan - többségben voltak az evangélikus vallásúak: 12 család 34 tagja tartozott e felekezethez (lásd 2. táblázat). A második legnagyobb csoportot közöttük a katolikusok alkották (11 család 15 tagja). A harmadik helyen álltak felekezeti sorrendben a reformátusok (5 család 1-1 tagja). Körükben tehát - a többi diákhoz viszonyítva - az evangélikusok felül voltak reprezentálva. Ez annak is köszönhető, hogy - ahogy láthattuk - az evangélikus családok nagyobb számban íratták be az iskolába gyermekeiket. Ami talán meglepő, az a katolikusok magas aránya. Hiszen ők, ha Pozsony városához ragaszkodtak, akkor beiratkozhattak volna a helyi királyi katolikus főgimnáziumba is.

2. táblázat. Az arisztokrata diákok felekezeti hovatartozása

\begin{tabular}{|c|c|c|c|}
\hline Vallás & Diák (fö) & Diák (\%) & Család \\
\hline Evangélikus & 34 & 62 & 12 \\
\hline Református & 5 & 11 & 5 \\
\hline Katolikus & 15 & 27 & 11 \\
\hline Nincs adat & 1 & 2 & 1 \\
\hline Összesen & 55 & 100 & 29 \\
\hline
\end{tabular}

Forrás: Értesitón 1867/68-1917/18.

3. táblázat. Az arisztokrata diákok tanulmányi státusza

\begin{tabular}{|c|c|c|c|c|}
\hline $\begin{array}{c}\text { Nyilvános } \\
\text { tanuló }\end{array}$ & Magántanuló & $\begin{array}{c}\text { Nyilvánosból } \\
\text { magán }\end{array}$ & $\begin{array}{c}\text { Magánból } \\
\text { nyilvános }\end{array}$ & Nincs adat \\
\hline 35 fó & 11 fó & 2 fó & 3 fó & 4 fö \\
\hline $64 \%$ & $20 \%$ & $4 \%$ & $5 \%$ & $7 \%$ \\
\hline
\end{tabular}

Forrás: Értesitón 1867/68-1917/18. 
Az iskola felekezeti jellegének nincs akkora jelentősége, ha a diák magántanuló. Érdemes ezért megvizsgálni a diákok státuszát. Láthatjuk (vö. 3. táblázat), hogy a többségük nyilvános tanuló volt. Ez azt jelenti, hogy a városban vagy az internátusban laktak. (Ez meglepő adat, hiszen a helyi királyi katolikus fógimnáziumban a fónemesek közt többségben voltak a magántanulók. ${ }^{80}$ ) Tizenegyen végig magántanulók voltak, öten pedig megváltoztatták tanulmányuk jellegét. Többen (7 fö) ismételték az előző osztályt. Erre őket ez vagy egy másik intézmény kötelezte. Négy egykori tanuló pedig eltávozott más iskolába, majd visszatért.

Ahogy fentebb említettük, érdemes összevetni a státuszt a felekezeti hovatartozással. Azt láthatjuk, hogy a mindvégig nyilvános tanulók közt nagy többségben voltak a protestánsok (21 evangélikus, 5 református). Úgy túnik tehát, hogy az iskolaválasztásban az iskola felekezeti jellege szerepet játszott. A katolikus tanulók közt kilencen tartoztak ebbe a kategóriába, s közülük - 7 evangélikus mellett - négyen voltak mindvégig magántanulók. Két katolikus diák először magántanuló volt, majd nyilvános tanuló lett. Feltehetjük a kérdést, vajon miért nem választották a katolikus diákok a helyi királyi katolikus főgimnáziumot? Ha a névsorokat összevetjük, kiderül, hogy közülük hárman ott kezdték gimnáziumi tanulmányaikat. A két Logothetty gróf mellett báró Clauer Elek, akinek azonban szintén voltak tanulmányi nehézségei: ő azonban nem ott ismételt osztályt, hanem ebben az iskolában. ${ }^{81}$ Érdemes megnézni a királyi katolikus főgimnáziumba járó főnemesi címmel rendelkező diákok névsorát; ott csak ritka kivételként találunk nem katolikus diákot. A két evangélikus közül az egyik báró Üchtritz Emil (1875-1934). Ố az I. osztályt még a felekezete szerinti gimnáziumban járta ki, majd - 2 év kihagyás (?) után - a katolikus iskolában folytatta tanulmányait. Itt is érettségizett 1894/95-ben. ${ }^{82}$ Gróf Hardenberg Károly az evangélikus gimnáziumban tanult három esztendeig, aztán átjelentkezett a katolikusba. A IV. osztályból azonban kilépett, aztán máshol tanult, majd egy évre (VI.) magántanulóként visszatért első iskolájába. ${ }^{83}$

Megvizsgáltuk, hogy a pozsonyi evangélikus fógimnáziumban hány tanévet kezdtek meg az arisztokrata diákok (lásd 4. táblázat). Látható, hogy a nagy többség, azaz az 55 fö 38\%-a mindössze egyetlen évre iratkozott be. Kevesen voltak köztük (22\%), akik 5-8 tanév elején is a tanulók közt szerepeltek. Azt mondhatjuk, hogy ugyan általában magas volt a fluktuáció a dualizmus korabeli középiskolákban, de ebben a társadalmi rétegben, amely többségében nem volt ráutalva ösztöndíjakra, s kiváltképp ebben az intézményben talán még az átlagosnál is nagyobb.

\footnotetext{
80 RÉBAY 2015, 255.

81 Értesítő 1877/78. 48.; Értesítő Pozsony kat. 1876/77. 49.

82 GudENus 1998, 160-161.; Értesítő 1885/86. 133.; Értesítő Pozsony kat. 1888/89. 79.; Értesítő Pozsony kat. 1889/90. 71.; Értesítő Pozsony kat. 1890/91. 85.; Értesítő Pozsony kat. 1891/92. 98.; Értesítő Pozsony kat. 1892/93. 64.; Értesítő Pozsony kat. 1893/94. 67.; Értesítő Pozsony kat. 1894/95. 51., 66.

83 Értesítő 1907/08. 102.; Értesítő 1908/09. 126.; Értesítő 1909/10. 100.; Értesítő Pozsony kat. 1910/11. 75.; Értesítő 1912/13. 101.
} 
4. táblázat. Arisztokrata diákok által megkezdett tanévek száma

\begin{tabular}{|c|c|c|c|c|c|c|c|c|}
\hline Tanév & 1 & 2 & 3 & 4 & 5 & 6 & 7 & 8 \\
\hline Fö & 21 & 10 & 6 & 6 & 3 & 4 & 1 & 4 \\
\hline
\end{tabular}

Forrás: Értesitő 1867/68-1917/18.

Összeszámoltuk, hogy az arisztokrata diákok mely osztályokba iratkoztak be az elemzett gimnáziumban (lásd 5. táblázat): a legtöbben a IV., a VIII. és az I. osztályba. Tehát sokan voltak azok, akik itt kezdték meg tanulmányaikat, s sokan, akik itt fejezték be.

5. táblázat. Arisztokrata diákok az egyes osztályokban

\begin{tabular}{|c|c|c|c|c|c|c|c|c|}
\hline Osztály & I. & II. & III. & IV. & V. & VI. & VII. & VIII. \\
\hline Fő & 22 & 18 & 17 & 24 & 18 & 15 & 19 & 23 \\
\hline
\end{tabular}

Forrás: Értesitő 1867/68-1917/18.

\section{Összegzés}

Eredményeinkből leszűrhetjük, hogy a pozsonyi evangélikus főgimnázium a dualizmus korában az arisztokraták körében veszített a vonzerejéből. Biró Zsuzsanna Hanna adatközlése alapján azonban összességében a felekezeti iskolák közt az érettségizettek tekintetében még így is a 7 , az evangélikusok közt pedig az 1 . helyen állt. Leszögezhetjük, hogy az iskolaválasztásnál a felekezeti hovatartozás lényeges, de nem kizárólagos szempont volt. Az iskolában tanuló arisztokraták többsége ugyanis evangélikus vallású volt. Számos példát találtunk a gyakori iskolaváltásra is, s egyes családok (pl. gróf Zay) esetén megállapíthattuk, hogy a szülők kimondottan az evangélikus iskolák között válogattak. A förangú diákok közt magas volt a nyilvános tanulók aránya, amelynek oka lehetett az is, hogy sok újabb, s idegen eredetű főnemes család sarja tanult az iskolában. Az iskola arisztokrata diákjai közül utóbb többen jelentős tisztséget töltöttek be: báró Feilitzsch Bertholdot főispánná nevezték ki, báró Buttler Elemért és gróf Zay Miklóst pedig országgyúlési képviselővé választották. 


\section{Források}

\section{Elsödleges források}

Értesítő Budapest 1900/01. = A budapesti ág. hitv. evang. fögymnasium értesitöje az. 1900/1901-iki iskolai évröl. Közzéteszi GÓBI Imre. Budapest, 1901.

Értesítő Budapest 1900/01. = A budapesti ág. hitv. evang. fógymnásium értesitőjje. 1879/80. Budapest, 1880.

Értesítő Budapest 1901/02. = A budapesti ág. hitv. evang. fögymnasium értesitöje ar. 1901/1902-iki iskolai évröl. Közzéteszi GÓBI Imre. Budapest, 1902.

Értesítő Győr 1883/84. = Értesitő a pannonhalmi Szent-Benedek-rend györi fögymnásiumáról az. 1883-84. tanév végén. Győr, 1884.

Értesítő Győr 1884/85. = Értesitő a pannonhalmi Szent-Benedek-rend györi fógymnásiumáról az 1884-85. tanév végén. Győr, 1885.

Értesítő Győr 1885/86. = Értesitô a pannonbalmi Sz-Benedek-rend gyôri fógymnásiumáról az 1885-86. tanév végén. Győr, 1886.

Értesítő Győr 1886/87. = Értesitô a pannonhalmi S₹-Benedek-rend györi fógymnásiumáról az 1886-87. tanév végén. Győr, 1887.

Értesítő Győr 1887/88. = Értesitő a pannonhalmi Sz-Benedek-rend györi fógymnásiumáról az 1887-88. isk. év végén. Győr, 1888.

Értesítő Komárom 1882/83. = Értesitô a pannonhalmi S₹. Benedek-rend rév-komáromi kath. kis-gymnasiumáról az. 1882/83-ik tanév végén. Komárom, 1883.

Értesítő Nagykanizsa 1876/77. = Kegyes-tanitórendiek vezetése alatt álló nagy-kanizsai kath. fógymnasium értesitöje az 1876-1877. tanévröl. Nagykanizsa, 1877.

Értesítő Pozsony 1867/68-1917/18. = LICHNER Pál (szerk., 1868): A pozsonyi ágostai hitvallású evang. főiskola értesítője az 1867/8-diki tanévről. Pozsony. (Megjelent 1867/68. és 1917/18. között minden tanévben változó címmel. Az egyes évfolyamok elérhetők a Hungaricana közgyüjteményi portálon - v. ö. https://library.hungaricana.hu/hu/collection/iskolai_ertesitok_pozsony_evangelikus_foiskola/ [2017.04.02.])

Értesítő Pozsony kat. 1870/71. = A pozsonyi kir. kath. fögymnasium értesitvénye az, 1870/1. évröl. Közli WIEDERMANN Károly. Pozsony, 1871.

Értesítő Pozsony kat. 1871/72. = A pozsonyi kir. kath. fögymnasium értesitvénye az. 1871/2. tanévröl. Közli WiEdermanN Károly. Pozsony, 1872.

Értesítő Pozsony kat. 1872/73. = A pozsonyi kir. kath. fögymnasium értesitvénye az 1872/3. évröl. Közli WiedermanN Károly. Pozsony, 1873.

Értesítő Pozsony kat. 1876/77. = A pozsonyi kir. kath. fögymnasium értesitöje az 1876/7 évröl. Közli WiedermanN Károly. Pozsony, 1877.

Értesítő Pozsony kat. 1888/89. = A pozsonyi kir. kat. fögymnasium értesitöje az 1888/89. iskolai évröl. Közli PIRCHALA Imre. Pozsony, 1889.

Értesítő Pozsony kat. 1889/90. = A pozsonyi kir. kat. fógymnasium értesitöje az 1889/90. iskolai évröl. Közli PIRCHALA Imre. Pozsony, 1890. 
Értesítő Pozsony kat. 1890/91. = A pozsonyi kir. kath. fögymnasium értesitöje az 1890/91. iskolai évról. Közli PIRCHALA Imre. Pozsony, 1891.

Értesító Pozsony kat. 1891/92. = A pozsonyi kir. kath. fógymnasium értesitóje az. 1891/92. iskolai évról. Közli PIRCHALA Imre. Pozsony, 1892.

Értesítő Pozsony kat. 1892/93. = A pozsonyi kir. kath. fögymnasium értesitöje az. 1892/93. iskolai évról. Közli PIRCHALA Imre. Pozsony, 1893.

Értesító Pozsony kat. 1893/94. = A pozsonyi kir. kath. fógymnasium értesitóje az. 1893/94. iskolai évról. Közli PIRCHALA Imre. Pozsony, 1894.

Értesító Pozsony kat. 1894/96. = A pozsonyi kir. kath. fógymnasium értesitóje az. 1894/95. iskolai évról. Közli PIRCHALA Imre. Pozsony, 1895.

Értesítő Pozsony kat. 1910/11. = A pozsonyi kir. kath. fögimnázium értesitóje az. 1910/11. iskolai évról. Közli POLIKEIT Károly. Pozsony, 1911.

Értesítő Selmecbánya ev. 1876/77. = Értesités a selmeci ágost hitv. evang. kerül. Lyceumról 1876/77. Közzé teszi BREZNYIK János. [Selmecbánya, 1877.]

Értesítő Selmecbánya ev. 1877/78. = Értesités a selmeci ágost hitv. evang. kerül. Lyceumról 1877/78. Közzé teszi BREZNYIK János. [Selmecbánya, 1878.]

Értesítő Selmecbánya ev. 1878/79. = Értesités a selmeci ágost hitv. evang. kerül. Lyceumról 1878/79. Közzé teszi BREZNYIK János. [Selmecbánya, 1879.]

Értesítő Selmecbánya ev. 1880/81. = A selmecbányai ágost. hitv. ev. kerül. lyceum értesitóje ą 1880/81 tanévról. Közzé teszi BREZNYIK János. Selmecbánya, 1881.

Értesítő Selmecbánya kat. 1874/75. = A selmecz̧bányai kir. kath. nagy-gymnasium tudósitványa. Az 1874-5-ik tanévról. Selmecbánya, 1875.

Értesítő Selmecbánya kat. 1875/76. = A selmeç̧bányai kir. kath. nagygymnasium értesitóje ą 1875/76 tanévról. Közli MÜLLNER Pál. Selmecbánya, 1876.

Értesítő Szeged 1872/73. = A kegyes tanitórendiek vezetése alatt álló szegedvárosi fögymnasium értesitvénye az 1872-73-ikei tanévröl. Szeged, 1873.

Értesítő Szeged 1874/75. = A kegyes tanitórendiek vezetése alatt álló szegedi városi fögymnasium értesitvénye az 1874-75-ikei tanévról. Közzéteszi: MAGYAR Gábor. Szeged, 1875.

FEILITZSCH Berthold (1933): Emlékeimböl! Budapest, Stádium Sajtóvállalat.

HU BFL - VII.101.d - rab. VI - 3356. A jogszolgáltatás területi szervei. Budapesti Királyi Országos Gyújtőfogház iratai. Rabtörzskönyvek, 1948, Marschall Ernő. https://archives.hungaricana.hu/hu/lear/Fogoly/38065/ [2017.04.02.]

Magyar Statisztikai Évkönyv. Új folyam XIX. 1911. (szerk., 1912): A Magyar Kir. Központi Statisztikai Hivatal. Budapest, Magyar Kir. Központi Statisztikai Hivatal.

MTI, Napi hírek 1932. június 4./6. kiadás. https://library.hungaricana.hu/hu/view/NapiHirek_1932_06_1/?qu-

ery $=\mathrm{SZO} \% 3 \mathrm{D}(\% 22 \mathrm{marschall} \% 20$ gyula $\% 22) \& \mathrm{pg}=119 \&$ layout $=$ s. [2017.07.02.]

Országgyúlési Főrendiház Irományai $=A z$ 1906. évi május hó 19-ére birdetett országgyülés förendibázának. irományai, I. (1906) Budapest, Pesti Könyvnyomda Rt.

Rangliste der k. u. k. Kriegsmarine richtiggestellt bis 27. Juni 1918. Wien, K. u. k. Hof- und Staatsdruckerei, 1918.

Változások és kitüntetések az erdészeti szolgálat köréből. Erdészeti Lapok (1917) 56. évf. 17-18. füzet, 452-454. 
Másodlagos források

BALLABÁS Dániel (2013): A magyar nemesség társadalmi tagolódása (16-20. század). In KollegA TARSOlY István - KovÁcs Eleonóra - PANDUlA Attila VITEK Gábor (szerk.): Genealógia 2. Budapest, Tarsoly Kiadó, 7-57.

FUKÁRI Valéria (2003): Egy régi alma mater. A pozsonyi evangélikus liceum és teológiai akadémia utolsó negyven éve (1882-1923). Pozsony, Kalligram.

FUKÁRI Valéria (2008): Felsö-magyarországi fóúri családok. A Zayak és rokonaik 16-19. száąad. Pozsony, Kalligram.

GUDENUS János Józse (1993): A magyarországi fónemesség XX. sqázadi genealógiája, II. Budapest, Tellér Kft.

GuDENUS János József (1990): A magyarországi fónemesség XX. sqázadi genealógiája, I. Budapest, Natura.

GuDENUS János József (1998): A magyarországi fơnemesség XX. szááadi genealógiája, IV. Budapest, Heraldika Kiadó.

GuDENUS János József (1999a): A magyarországi fónemesség XX. sqáąadi genealógiája, III. Budapest, Heraldika Kiadó.

GuDENUS János József (1999b): A magyarországi fơnemesség XX. sqáaadi genealógiája, V. Budapest, Heraldika Kiadó.

HAEFFLER István (szerk., 1940): Országgyülési almanach. Az 1939-44. évi országgyülésrôl. Budapest.

HALÁsz Sándor (szerk., 1887): Országgyülési almanach 1887. Förendiház. Budapest.

KEPECS József (szerk., 1996): A Felvidék településeinek nemzetiségi (anyanyelvi) adatai százalékos megoszlásba (1880-1941). Budapest, Központi Statisztikai Hivatal.

LUKINICH Imre (1943): A podmanini Podmaniczky-család története. Budapest, Magyar Tudományos Akadémia.

MARKUSOVSZKY Sámuel (1896): A pozsonyi ág. hitv. evang. lyceum története kapcsolatban a pozsonyi hitv. ág. evang. egyház múltjával. Pozsony, Wigand Nyomda.

MÉSZÁROS István (1988): Középszintü iskoláink kronológiája és topográfiája 996-1948. Általánosan képrō középiskolák. Budapest, Akadémiai Kiadó.

PETRY Gyula (1900): Az aszódi ág. hitv. evang. algymnasium történetének vázlata az 1887/88. év végéig. In $A z$ aszódi ágostai hitv. evang. algymnasium értesitóje az. 1900/1901. iskolai évről. Közli BOLLA Lajos. Aszód, 3-49.

PLACHY Bertalan - PIRCHALA Imre [1904]: Közoktatásügy. In BOROvSzKY Samu (szerk.): Magyarország vármegyéi és városai. Pozsony vármegye. Budapest, Apollo Irodalmi Társaság. http://mek.oszk.hu/09500/09536/html/0017/19.html. [2017.03.19.]

PODMANICZKY Pál története. Cultura. 2015. március 22. http:/ / cultura.hu/kultura/podmaniczky-pal-tortenete/. [2017.03.28.]

Pozsony. In Pallas Nagylexikon. http://mek.oszk.hu/00000/00060/html/084/pc008400.html\#7. [2017.03.24.]

RÉBAY Magdolna (2015): Arisztokrata jelenlét a pozsonyi királyi katolikus főgimnáziumban a dualizmus korában. In BASKA Gabriella - HEGEDŰs Judit (szerk., 
2015): Égi iskolák, földi mühelyek - Tanulmányok a 65 éves Németh András tisðteletére. ELTE PPK, Budapest, 250-258.

RÓZSA Dávid (főszerk., 2014): Portrék a magyar statisqtika és népességtudomány történetéböl. Életrajzi lexikon a XVI. századtól napjainkig. Budapest, Központi Statisztikai Hivatal Könyvtár.

SCHIMkÓ Frigyes Dániel. In SzINNYEI József (é. n.): Magyar irók élete és munkái. http://mek.oszk.hu/03600/03630/html/s/s23014.htm. [2017.03.21.]

STURM Albert (szerk., 1892): Orsqággyülési almanach 1892-1897. Budapest.

STURM Albert (szerk., 1897): Országgyülési almanach 1897-1901. Budapest.

STURM Albert (szerk., 1901): Országgyülési almanach 1901-1906. Budapest.

SzARKA László (2005): Pozsony etnikai változásai és a városi közigazgatás a két világháború között. In CZOCH Gábor (főszerk.), KOCSIS Aranka (szerk.), TÓTH Árpád (szerk.): Fejezetek Pozsony történetéböl magyar és szlovák sz̧emmel. Pozsony, Kalligram, 401-419.

SzEMERJAI DEÁK Imre (szerk., 1927): Magyar Országgyülési Almanach 1927-1932. (Dr. Deák-féle) Budapest.

Vutkovich Ödön [1904]: Pozsony. In Borovszky Samu (szerk.): Magyarország vármegyéi és városai. Pozsony vármegye. Budapest, Apollo Irodalmi Társaság. http://mek.oszk.hu/09500/09536/html/0017/19.html. [2017.03.19.] 